\title{
Employee Benefits and its Effect on Productivity at Semcon India Private Limited, Bangalore\#
}

\author{
Sumithra Sreenath ${ }^{1 *}$, P. Arathy Mohan ${ }^{2}$ and M. P. Lavanya ${ }^{2}$ \\ 'Professor, M P Birla Institute of Management, Bangalore, India \\ ${ }^{2}$ MBA Student, M P Birla Institute of Management, Bangalore, India
}

\section{Abstract}

Reward management is the key to motivate employees in the present scenario of the work environment. Many researchers have deliberated on the same points that employ benefit packages will motivate employees at the workplace. In the case of benefits monetary benefits like cash rewards and insurances are most preferred by the employees. Many compensation personnel usually are in the state of fix to identify the right kind of benefit and most suitable to retain employees at the workplace. The Head of HR's think about the ideal plans for offering a holistic compensation package. Usually benefit packages are kept a part of flexible plans and annually it is changed.

Moreover designing the best benefit package is challenge to the compensation executives or third parties which manage payrolls in today's environment. One more important point to be considered at this juncture, it is understood that each industry or each organisation has set their own method of benefit packages. It is a daunting task to understand the best methods of benefit packages which motivate employees. Some of the organisations follow the industry or market place standards to offer the benefit packages, but is helping employees in motivating and helping them to improve productivity is a question mark.

Off late, keeping employee's morale and seeking their productivity is a challenge, but of course, work environment matters a lot at the same time some specific employee benefits matter a lot. Today's employee expects flexible time, work from home, team events, learning opportunities, family care programs, awards ,rewards, perquisites, pension funds, break encouragements, leave travel allowance, family time out and other benefits are important for encouraging employees at workplace. Corporate caring for employee's health and happiness makes all round impact on the work environment and retention of employees. Many researchers have presented a detailed point on giving breaks to employees is an important phenomenon.

In this paper the authors have made an effort to understand the type of benefit packages given in the engineering company called 'Semcon' India private limited. The authors have made all the efforts to collect data from almost all employees who were present during the time of data collection at the industry. The instrument used to collect data is through structured questionnaire with the variables consisting of recognition, mobile and internet benefit, leave policy, performance, productivity and educational benefit in order to link that with the productivity and identify the impact of the variables. In this paper the authors have used SPSS statistical package for correlation and chi-square tests. Sample size chosen for the study for the study 108 employees of Semcon. The data was collected from 72 males and 36 females. The study finally concluded that employee benefit packages do impact the productivity at the workplace.

Keywords: Benefits and Allowances, Performance, Productivity, Recognition

*Email: mpbimsumsree@gmail.com

"This is the Revised and modified version of the article, originally presented in the $7^{\text {th }}$ International Conference on Managing Human Resource at the Work Place, December 14-15, 2018, SDMIMD, Mysuru, India. 


\section{Introduction}

Employee benefits are discretionary, non-wage pay gave to representatives notwithstanding their typical wages or compensations. The expression of "employee benefits" is a broad concept that incorporates protection schemes, completely remunerated to cover the deficiencies (get-away, occasions, wiped out leave), annuities, stock possession designs, and manager gave administrations, (for example, youngster mind) offered by bosses to their representatives. These benefits deliver additionally alluded to as incidental advantages to the working class. However different advantages now and again are dealt by government sector at different levels of salary for compulsory deduction purposes. These incorporate rewards, benefit distribution, and covering arrangement of taxi services or lodging. All "edges" clearly outlines the business' choice; along these lines manager commitments to plans for retirement, like Medical facility, basic medical treatments, Workers' reward management and different projects are to be given priority; as they are of primary importance under law.

\section{Global Scenario of Benefits for Employees}

As the representative advantages in the industry, US had attempted to adjust the 'Affordable Care Act', recently Trump's 'nullification and supplant' motivation is influencing numerous individuals to feel awkward. US president's latest proposal is ensuring absence of specificity isn't easing this stress, but added proclamation guaranteed to cancel Obamacare get rid of laws that repress health care coverage merchants to offer crosswise over state lines; enable people to deduct medical coverage premium installments from their expense forms; enable people to utilize HSAs; constrain social insurance suppliers' expenses to be straightforward; and square concede Medicaid to the states. The country has effectively made strides towards supplanting Obamacare, particularly 'watching benefits scenario'.

The most recent ten years in Australian worker benefits have been portrayed by managers' needs to diminish expenses and dangers joined with the progress to representative self-service. The statistic changes in progress in Australia show an on-going relative deficiency of more youthful new participants to the workforce. Upper hand will be improved for those businesses that adjust and give worker rewards, including compensation and advantages that are both financially savvy and alluring to the creating workforce.

\section{Indian Scenario of Employee Benefits}

Corporate brought together government managed savings system; what so ever standardized savings is accessible is overwhelmingly welfare-orientated with no arranged budgetary reach. Moreover, one of the other difficulties is that, as every segment of corporate standardized savings framework has grown independently, there is no office in charge of a framework wide point of view. In this manner, the greater parts of the statutory and discretionary corporate advantages have developed autonomously. Strangely, approximately $15 \%$ of the present working population takes an interest in the mandatory, formal programs intended to give wage security amid systematic methods. Besides, these members (salaried workers in the formal private area and in government employments) are among the most noteworthy wage workers in Corporate.

Beyond all, the origin of the benefits of employee's in the time of industrial revolt. Little salaries extended working hours, uninteresting and unsafe work, and obnoxious administrative practices ran to high employee turnover, intense attacks, and the risk of social unpredictability. These headed to numerous labour unions calling for organizations to reimburse employees in the monetary terms. Consequently, at the end of 19th century, the industrial relations committees were formed. The committees recommended benefits as a part of wage, but it was left to the companies for the decisions of blue collar work or white collar workers. In order to give right benefits to the employees, also to motivate them to be more productive more companies adhered to the benefits. "The most comprehensive definition of the employee benefits was surprised by 
the International Accounting Standard (IAS 19), which indicates that the employee benefits are all forms of consideration given by an entity in exchange for service rendered by employees. Also, IAS 19 identifies and classifies these benefits into five categories namely: short- term employee benefits, post- employment benefits, and other long- term benefits, benefits for the employment, termination and contract. There are points mentioned in the clause about compensation in the form of the equity participations (Mirea, Naftanaila, 2012). The law used in the employee benefit is "Employee Benefits Act".

At recent times, the some plans which have been introduced have new forms of coverage for the employees in the organisation. The organization gave more suitable benefit in a cheaper cost. The type of benefits offered are teleporting options, payment for gas, childcare or day care facility and training for skill up gradation. Some of the contemporary benefits were dropped in the last two or three years and started the inventive types of benefits such as cell phones are sponsored for personal use of company, memberships forfitness centre and on- site vaccinations for employees. Most of the organizations are alert in giving medical benefits to the family which includes dependents. Some of the organizations embraced mobile expenses based on the position held and to cover the expenditure for calling customers who may be present across national boundaries. Many organisations, as a matter of practice have accommodated travel benefit/expenses or can be called as business trip which includes airfares, train travel bookings, hotel stays, outstation allowance and travel insurance.

Moreover, the flexible benefits which are given to the employees are considered more valuable because these plans will cover the health cum hospitalization expenses also. So it acts as greater advantage for employees in saving that part of expenditure. Flexible benefit insurance plans are used by the companies to help employees with the options to cover different requirements of health ailments. Some of the employers have fixed limits of the cost covers based on the levels in the organisations. This may negatively affected the both recruitment and retention. In a most organizations, flexible plans have been introduced to benefit employees to cover different kinds of aliments as a part of health cover.

The other benefit is for teams, as many of the activities in the organisations involve teams and rewarding team is a must for creating official bonding. So these will help to employees to understand the work and culture. In the meantime, the other one is learning opportunities so many organisations do give benefits for employees for academic achievements. Some of them give loan to precede with higher education do the all help for the employees for further studying. So this may motivate employees for better performance for the company. The other benefit program is family care programs, in recent all the companies give the child care; this is the form of family care. Some companies provide elderly care, pet care and other forms help because the employees are less stress and they are concentrated in working. The other one is awards and rewards for the better performance, this is the type of motivation and this is the advantage for increasing productivity. All the employees take the better performance in the company. The other benefit is break encouragement; the some organizations implemented a culture that grimaces on break all over the day. Some people are working after the stretched periods of time and working in lunch time also. That people are working hard compared to others. These benefits are suitable for increasing the productivity. These benefits are making good changes in the employee and they are more productivity. The employee productivity is increased then the organization is reached in the top level.

\section{Profile of the Selected Organisation}

Semcon is a Swedish company and it is a multinational technology company. The company mainly focuses on the product development. It has also teamed up with the companies in the field of automobile industry and the energy and sectors of life science. The company was founded in the year of 1980. The first company was located in Vasteras, Sweden. The headquarters of the company is Gothenburg. As per 2017, 2000 employees are working in Semcon. The type of the company is 
public company. The current CEO of the company is Markus Granlund and current Chief Financial Officer is Bjorn Stromberg. The company was listed on the Stockholm Stock Exchange.

Semcon India Private limited is established in the year March 2006 at Bangalore where around 120 employees are working. The core businesses of Semcon's are engineering services and product information. In engineering services also have three main areas. These are development of product, development of production and design of plant. These includes the engineering for vehicles, Mechanical related activity, Electrical oriented designs and computerised designs, completely automated tests and check, simulated designs and a chance for user experience, new venture management, standard and mechanism development and modulation. In product related info, they also have the few main areas these are communication though internet via, after product manufacturing info and dispersing of statistical facts. These include facts on strategy, design, efficient service, Online information on product and brand related activities, facts about organisations, product facts, facts on, utilities, availability of spare parts and accessories info, examples on visual and dissemination in online way. The company's long term vision is, for positive towards employee welfare and development, by offering, appropriate systems and operations. The vision for employees is "To attract, preserve and develop the best talent in the company through the solid brand and the prosperous culture".

\section{Literature Review}

There are more researches contributing to care for the wellbeing of the working class in the area of employee benefits linking to productivity. The research work depicts from ancient management theory till recent times. This particular work concentrates on the journal publications which have been done in the recent past in order to establish a link to the theme.

Reddick (2009), this study deals with comparing health benefits of private sectors and public sectors employees. The data for the study obtained from the country's assessment of physical condition of human beings and welfare facility conducted by the "Kaiser Family Foundation" (KFF) also includes coaching on normal physical condition. Health and family welfare programs are used to attract the talented chunks for service oriented careers. The main aim of this study is conduct a comparison of the quasi government owned organisations and others. Moreover, another point is to examine factors that forecasts the more priority towards community's temptation by offering welfare measures. The benefits satisfaction is more positively oscillated towards orderliness, principle based administration of the firm. Models presented in the study, test the connections between qualities of associations and medical advantages are sketched out. Research demonstrates that more noteworthy decision of wellbeing designs prompts expanded representative fulfillment. This study discovered the distinctive kinds of wellbeing designs affect the significance joined to medical advantages. The most critical discoveries of this examination are general society segment firms have more good feelings than the private part associations with respect to medical advantages being vital for incremental productivity.

Moreover, Thierry Poulain-Rehm and Xavier Lepers (2012), the focus of the study is employee ownership and its role in value creation. The result from the study shows that employee's ownership plan has no role on value creation for employers. Employee ownership deals with employee holding a few shares of the company. In the strategic decision making shareholders were given precedence in the traditional way of governance. The more recent debate on the governance, which takes into account shareholders interest especially that of customer's employers and suppliers. The change in the perspective can be attributed to the growing interest in Business Ethics and social responsibility. Due to the increasing Global competition and the economic crisis and to satisfy all the stakeholder governance and shareholder governance is taken as theoretical reference. The study uses empirical and theoretical reference to presents the importance of proprietorship in worth designing for an organization. The details study on the influence of possessing on the worth designing request to differentiate the shares which are owned by managers and employers. 
Stephanie C. Kern (2013), there is very few studies done on job satisfaction when it comes to women and even less when we consider women in manufacturing sector. Due to the very few study available, it is difficult to give timely information on the effectiveness of benefits provided to the women employee in manufacturing industry. The purpose of the study is to examine whether there is a relation between job satisfaction and benefit provided to the women employee in the manufacturing sector. There is a substantial increase in the number of women employees. The studies conducted earlier showed that women employee in manufacturing and other physically demanding jobs are not happy with the employee benefits. Earlier studies have also showed that women employees are more satisfied with their employer if work-life balance issues are addressed. The method followed was collecting data from anonymous surveys from the entire employee. Online tools to retrieve data from the survey were used to gather data. The answer was collected for both male and female employees later the data was narrowed down to female employees. The study highlighted that the job role is very important in job satisfaction.

Frank Giancola (2013), to design an effective benefit plan it is important to know happy with the existing benefit plan. If the firms, routinely does the survey on both the question, they can with their intelligence make or design benefit plan which can satisfy everyone. But unfortunately, the surveys are not routinely done by the employers. From the surveys, $37 \%$ of the employees were satisfied with their wages. The overall conclusion from the study was employees are satisfied with their benefit plan. But there low in satisfaction when it comes to rising healthcare costs and premiums. The survey shows that employee benefits are important for satisfying and attracting employees. The survey also points to the beneficial plan which the employee thinks or considers being more important than the other. The survey also shows that human resource personal was under an impression that HR programs are important for employees than benefit plan. The organizations which have satisfied employees are more productive in their work when compared to fewer satisfaction levels.

Michael Custers (2013), the workers and employers see stagnant salaries as a challenge. The companies can recognize their employees other than cash. The benefits which increase their work life balance and which enhances their professional performance can be very helpful for employee motivation and loyalty. By providing such benefits it will result in well trained and more experienced workforce. Non-mandatory benefits which companies can provide to their employees can be easily designed with help of HR technologies. The compensation and the benefit landscape of the workforce can be surveyed using HR technologies. New benefits can be planned using HR tools. HR learning tools can give might on the training needs of their workforce. Having flexible work schedule is other important benefit for any employee clients, employers and employees can use Cloud based services to connect from anywhere in the world. Attendance and time based HR solutions can be used by companies to enhance their benefits. Understanding this system will help employees to offer holiday for their employee on low work demand days. HR solutions also help employers to know value of their existing benefits.

Matthew Owenby (2014), the decision taken by the employer regarding the health care benefit has implication on the workforce which the employers should examine. The changes in employee benefit plan will result in financially stressed workforce which may result in productivity loss. According to the report, the employees reported that issues relating to personal finances are the top non work issue which distracts the employee from their day to day work. Due to the financial stress, employees fail to report and also loss in periodicity. Most of the population said they would face financial burden if they are not able to work or disabled by any means. To help employees focus on their job without financial worries, disability insurance is a good and effective option. Some employers feel that the disability insurance is an added expense to their business. By adding disability insurance to its benefits plan, it can help hire and attract new employees. In any instant anyone can become disabled due to an accident or any illness. But most of them do not think about it or assume that something of this kind will never happen to them. The employees who are the only source of income to their family will be left with no income but with higher health costs. Disability insurance will help 
to cover the medical expenses which are not covered by the primary health plans.

Miles Varn (2014), employers when talked about cost of health care, always focus on the premiums being paid and different program that can help reduce the cost on health care. Due to the employee illness, companies not only suffer on health care but also suffer on loss of productivity and also lower performance on job. Medical costs that are unnecessary can be attributed to number of factors. Families of the patients who have suffered serious injury or illness are always forced in a highly stressful environment. They are forced to take more complex decisions for which they are ill equipped. Misdiagnoses also lead to some unwanted procedures and the treatment can have impact on the health. Another factor that contributes to the unwanted medical expenses is because of the lack of communication between care givers. Cost productivity cannot be always attributed to absenteeism. Employees who are dealing with other own illness or any of their family members, when attend their work are also less productive. Health advisory services can be a guide to the employees facing serious diagnosis. Employees can seek second optimum from the experts in the field. Receiving care from the experts will reduce the need for unwanted procedures. Employees are empowered to decision makings for their medical treatment.

Jaya Bhalla (2015), flexible working arrangements can affect the either directly or indirectly to the improvement of the individual as well as organisation and social wellbeing. Initially the adaptability in the work put was presented for ladies who have the consideration duty by giving her the maternity leave and a few relaxations at the working spot. Many companies have begun to offer flexible work arrangements to help employee balance work and family demands. Flexible working arrangement are defined as employer provided benefits that permit some level of control over when and where they work outside of the standard workday. The studies done between of 1983 to 2011 was studied and discussed. This examination builds up the connection among free and wards factors. The investigation is explanatory in character or reason as diagnostic research includes inside and out examination and assessment of accessible data trying to clarify complex phenomenon. The study mainly depends on data collection from primary sources through distributing questionnaires that is specially designed for the study. Five-point Likert scales have been used in the questionnaire to measure effect of flexible working arrangements on employee productivity.

Marilyn Spencer, Deniz Gevrek et al., (2015), the effect of low cost worker advantage program on maintenance and the representative execution is the primary focal point. The study was done by surveying employees of a public university. The cost of employee resigning and a new recruitment which replaces the resigned is 20 percent. The one way to tackle this problem was by providing robust employee benefit plan. The study showed that the employers who offer robust benefit plan have satisfied employees who are more likely to stay in their present job. Then those employees who are not satisfied with their benefit programs. The study measures two ward factors, worker maintenance and representative efficiency. For the organizations of advanced education, representative maintenance and their profitability are need. The result suggests that waiver on tuition, annual salary and dependents are significant to raise productivity as well as encourage them to retain for longer at their present job. Also classification of staff is also essential for employee retention. The major outcome or conclusion from the study was by introducing new tuition waiver which is relatively low cost will help in employee retention and productivity.

\section{Objectives of the Study}

- To identify benefit packages offered to the employees.

- To examine the effects of employee benefit packages on the overall performance.

\section{Research Methodology}

The present study is included both in exploratory research and descriptive research as it completely focuses on a phenomenon called "Employee Benefits", which tries to understand the extent of benefits 
provided at the work place named "Semcon India Private limited". The study is completely relying on the primary data. The primary data is collected through structured questionnaire.

Sampling: The sample size taken is 108 respondents. Sampling technique used is domain (employees). The study covers almost all employees in the organization, who are present during the time of data collection. Tools used for Analysis: Simple Percentage Analysis, Multiple Correlations and usage of "Chi-square tests" for analysis of the data. The data fed into "IBM SPSS 20" for treatment.

\section{Data Analysis and Interpretation}

\subsection{Reliability Statistics}

Table 1. Case summary

\begin{tabular}{|l|l|l|l|}
\hline \multicolumn{2}{|c|}{} & N & $\%$ \\
\hline \multirow{4}{*}{ Cases } & Valid & 108 & 100.0 \\
\cline { 2 - 4 } & Excluded $^{\mathrm{a}}$ & 0 & 0 \\
\cline { 2 - 4 } & Total & $\mathbf{1 0 8}$ & $\mathbf{1 0 0 . 0}$ \\
\hline
\end{tabular}

Table 2. Reliability statistics

\begin{tabular}{|l|l|l|}
\hline Cronbach's Alpha & Based on Standardized Items & N \\
\hline .795 & .795 & 14 \\
\hline
\end{tabular}

The dependability of data is 0.795 the numbers are near 1 . Generally the coefficients ought to be above 0.7 which are considered as having great consistency. Subsequently the consequence of the (Table $1 \& 2$ ), indicates 0.79 is information is good.

\subsection{Demographic Details of the Respondents}

It is evident from the (Table 3), demographic details of the respondents that majority of them belong to $(72 / 108)$ 66 percent are males and the rest $33(36 / 108)$ percent are females. Based on the age classification of the respondents the highest number representation is from 26-30 with 46 and second highest 31 of them belong to the age group of 31-35. The third highest that is 20 of them belong to the age of 21-25. The next category is the income, which is very important as it decides on the capacity and spending of individuals. (Table 3), it is inferred that income classification almost 24 percent

Table 3. Profile of the respondents

\begin{tabular}{|c|c|c|c|}
\hline Variables & Categories & No of Respondents & Percentage \\
\hline \multirow[t]{2}{*}{ Gender } & Male & 72 & 66.67 \\
\hline & Female & 36 & 33.33 \\
\hline \multirow[t]{5}{*}{ Age } & $21-25$ & 20 & 18.52 \\
\hline & $26-30$ & 46 & 42.59 \\
\hline & $31-35$ & 31 & 28.70 \\
\hline & $36-40$ & 10 & 9.26 \\
\hline & 41 and above & 1 & 0.93 \\
\hline \multirow[t]{4}{*}{ Monthly income in Indian currency (Rs) } & $21,000-30,000$ & 18 & 16.67 \\
\hline & $31,000-40,000$ & 22 & 20.37 \\
\hline & $41,000-50,000$ & 24 & 22.22 \\
\hline & 51,000 and above & 44 & 40.74 \\
\hline \multirow[t]{3}{*}{ Education } & Graduate & 51 & 47.22 \\
\hline & Post Graduate & 57 & 52.78 \\
\hline & Others & 0 & 0 \\
\hline \multirow[t]{2}{*}{ Marital status } & Married & 60 & 55.56 \\
\hline & Unmarried & 48 & 44.44 \\
\hline
\end{tabular}


belong to group of Rs 41000-50000 monthly earnings and 44 percent of them belong to the income group of Rs 51000 and above monthly earnings. The rest of them distributed among Rs 21,000-30,000. Among the respondents 57 of them were post graduates and 51 of them are graduates. In the category of marital status 60 were married and 48 of them belong to unmarried category (Table 4).
As per the (Table 5), the correlations factors which is analyzed with all dimensions found to be positive and significant at (two tailed). It also shows that the null hypotheses is rejected with all the five dimensions like Productivity, Performance, leave policy, educational benefit recognition and mobile internet benefit. However observing the correlation values it shows high relation in the case of leave policy.

Table 4. Chi square

\begin{tabular}{|l|l|l|l|l|}
\hline \multirow{2}{*}{1.} & $\mathrm{H}_{0}:$ There is no relationship between productivity and performance. & $5 \%(0.05)$ & $\mathrm{P}=0.013$ & $\mathrm{H}_{0}$ is rejected \\
\cline { 2 - 5 } & $\mathrm{H}_{1:}$ There is relationship between productivity and performance. & & $\mathrm{H}_{1}$ is accepted \\
\hline \multirow{2}{*}{2.} & $\mathrm{H}_{0:}$ There is no relationship between productivity and leave policy. & $5 \%(0.05)$ & $\mathrm{P}=0.827$ & $\mathrm{H}_{0}$ is accepted \\
\cline { 2 - 5 } & $\mathrm{H}_{1:}$ There is relationship between productivity and leave policy. & & $\mathrm{H}_{1}$ is rejected \\
\hline \multirow{2}{*}{3.} & $\mathrm{H}_{0:}$ There is no relationship between productivity and educational benefit. & $5 \%(0.05)$ & $\mathrm{P}=0.001$ & $\mathrm{H}_{0}$ is rejected \\
\cline { 2 - 5 } & $\mathrm{H}_{1:}$ There is relationship between productivity and educational benefit. & & $\mathrm{H}_{1}$ is accepted \\
\hline \multirow{2}{*}{4.} & $\mathrm{H}_{0:}$ There is no relationship between productivity and recognition. & $5 \%(0.05)$ & $\mathrm{P}=0.000$ & $\mathrm{H}_{0}$ is rejected \\
\cline { 2 - 5 } & $\mathrm{H}_{1:}$ There is relationship between productivity and recognition. & & $\mathrm{H}_{1}$ is accepted \\
\hline \multirow{2}{*}{5.} & $\mathrm{H}_{0:}$ There is no relationship between productivity and financial benefit. & $5 \%(0.05)$ & $\mathrm{H}_{0}$ is accepted \\
\cline { 2 - 5 } & $\mathrm{H}_{0:}$ There is relationship between productivity and financial benefit. & & $\mathrm{H}_{1}$ is rejected \\
\hline \multirow{2}{*}{6.} & $\mathrm{H}_{0:}$ There is no relationship between productivity and mobile/ internet benefit. & $5 \%(0.05)$ & $\mathrm{P}=0.009$ & $\mathrm{H}_{0}$ is rejected \\
\cline { 2 - 5 } & $\mathrm{H}_{1:}$ There is relationship between productivity and mobile/ internet benefit. & & $\mathrm{H}_{1}$ is accepted \\
\hline
\end{tabular}

Table 5. Correlations

\begin{tabular}{|c|c|c|c|c|c|c|c|}
\hline & & Pro-ductivity & Perfor-mance & Leave policy & Edu-cational Benefit & Recog-nition & $\begin{array}{l}\text { Mobile/Internet } \\
\text { Benefit }\end{array}$ \\
\hline \multirow[t]{5}{*}{ Productivity } & Pearson Correlation & 1 & $.421^{* *}$ & 0.176 & 0.249 & $.322^{+*}$ & 0.339 \\
\hline & Sig. (2-tailed) & & 0 & 0.069 & 0.009 & 0.001 & 0 \\
\hline & $\begin{array}{l}\text { Sum of Squares and } \\
\text { Cross-products }\end{array}$ & 530 & 255 & 100 & 193 & 213 & 284 \\
\hline & Covariance & 4.953 & 2.383 & 0.935 & 1.804 & 1.991 & 2.654 \\
\hline & $\mathrm{N}$ & 108 & 108 & 108 & 108 & 108 & 108 \\
\hline \multirow[t]{5}{*}{ Performance } & Pearson Correlation & $.421^{* *}$ & 1 & $.359^{* *}$ & $.399^{* *}$ & 0.452 & $.441^{* *}$ \\
\hline & Sig. (2-tailed) & 0 & & 0 & 0 & 0 & 0 \\
\hline & $\begin{array}{l}\text { Sum of Squares and } \\
\text { Cross-products }\end{array}$ & 255 & 692.546 & 233.657 & 353.213 & 341.38 & 421.731 \\
\hline & Covariance & 2.383 & 6.472 & 2.184 & 3.301 & 3.19 & 3.941 \\
\hline & $\mathrm{N}$ & 108 & 108 & 108 & 108 & 108 & 108 \\
\hline \multirow[t]{5}{*}{ Leave Policy } & Pearson Correlation & 0.176 & $.359^{* *}$ & 1 & 0.26 & $.268^{* *}$ & 0.434 \\
\hline & Sig. (2-tailed) & 0.069 & 0 & & 0.007 & 0.005 & 0 \\
\hline & $\begin{array}{l}\text { Sum of Squares and } \\
\text { Cross-products }\end{array}$ & 100 & 233.657 & 611.435 & 216.324 & 190.491 & 390.287 \\
\hline & Covariance & 0.935 & 2.184 & 5.714 & 2.022 & 1.78 & 3.648 \\
\hline & $\mathrm{N}$ & 108 & 108 & 108 & 108 & 108 & 108 \\
\hline
\end{tabular}




\begin{tabular}{|c|c|c|c|c|c|c|c|}
\hline \multirow{5}{*}{$\begin{array}{l}\text { Educational } \\
\text { Benefit }\end{array}$} & Pearson Correlation & $.249^{*+}$ & $.399^{+*}$ & $.260^{*+*}$ & $1^{\text {** }}$ & $.524^{* *}$ & $.527^{*+}$ \\
\hline & Sig. (2-tailed) & 0.009 & 0 & 0.007 & & 0 & 0 \\
\hline & $\begin{array}{l}\text { Sum of Squares and } \\
\text { Cross-products }\end{array}$ & 193 & 353.213 & 216.324 & 1133.88 & 506.046 & 645.065 \\
\hline & Covariance & 1.804 & 3.301 & 2.022 & 10.597 & 4.729 & 6.029 \\
\hline & $\mathrm{N}$ & 108 & 108 & 108 & 108 & 108 & 108 \\
\hline \multirow[t]{5}{*}{ Recognition } & Pearson Correlation & 0.216 & 0.447 & 0.332 & $.524^{* *}$ & $1^{* *}$ & $.530^{*}$ \\
\hline & Sig. (2-tailed) & 0.025 & 0 & 0 & 0 & & 0 \\
\hline & $\begin{array}{l}\text { Sum of Squares and } \\
\text { Cross-products }\end{array}$ & 182 & 430.481 & 300.037 & 506.046 & 823.213 & 552.898 \\
\hline & Covariance & $1.701^{\star \star}$ & 4.023 & $2.804^{\star \star}$ & 4.729 & 7.694 & 5.167 \\
\hline & $\mathrm{N}$ & 108 & 108 & 108 & 108 & 108 & 108 \\
\hline \multirow{5}{*}{$\begin{array}{l}\text { Mobile and } \\
\text { Internet benefit }\end{array}$} & Pearson Correlation & 0.216 & 0.447 & 0.332 & $.524^{\star \star}$ & $.530^{\star}$ & $1^{\star \star}$ \\
\hline & Sig. (2-tailed) & 0.025 & 0 & 0 & 0 & 0 & \\
\hline & $\begin{array}{l}\text { Sum of Squares and } \\
\text { Cross-products }\end{array}$ & 187 & 460.481 & 307.037 & 5086.046 & 824.213 & 556.897 \\
\hline & Covariance & $1.601^{\star \star}$ & 4.023 & $2.804^{\star \star}$ & 4.729 & 7.694 & 5.166 \\
\hline & $\mathrm{N}$ & 108 & 108 & 108 & 108 & 108 & 108 \\
\hline
\end{tabular}

\section{Discussions}

The study presents the five different types of benefits provided by Semcon. In this particular study, variables chosen were Productivity, Performance, leave policy, educational benefit, Recognition and mobile and internet benefit. Mobile and internet benefit is used by the employees when they travel abroad. Most of the employees are happy about the benefits provided by the company. The authors would like to state that medical benefits and group insurance are not covered in the study. A point of suggestion was that spectacle allowance can add more motivation to the employees. Moreover benefits need to be kept flexible and it has to be reviewed from time to time.

\section{Conclusion}

The study covers only some part of the benefits plans provided by the company chosen for the study. The authors would like to mention that perks and recognition can more motivate employees at the work places. A deeper dig into a comparative study can reveal more motivational benefits and company can make choices for the betterment of the employees. Finally the authors would like to conclude that there is a strong relationship between employee benefits and productivity.

\section{Bibliography}

Christopher G. Reddick (summer 2009). The importance of employee health benefits to public and private sector organizations, Public Personnel Management; Vol.38 (2); ABI/INFORM Global, pg. 49-68.

Frank Giancola (July 2013). How Important Are Benefit Plans to Your Employees and How Satisfied Are They with Your Offerings, p. 27-30.

Jaya Bhalla (January-July 2015). Impact of flexible work arrangements on productivity in Indian IT sector: A study, IPE Journal of Management. 6(1):80-104.

Marilyn Spencer, Deniz Gevrek, et al. (June 2015). Labor supply and productivity responses to non-salary benefits, do they work? If so, at what level do they work best? 45(5):1047-68.

Matthew Owenby (July 2014). Disability Insurance Benefits Impact Employees' Financial Outlook, p. 14-15.

Michael Custers (February 2013). HR Technologies Guide Employers to Better Benefits Offerings, p. 20-21. 
Miles Varn (May 2014). The Cost of Employee Illness to Business: New Approaches for Managing Costs and Improving Care, p. 27-29.

Stephanie C. Kern (March 2013). A Study of the Effectiveness of Benefits on the Job Satisfaction of Women in Manufacturing, p. 1-112.

Thierry Poulain-Rehm \& Xavier Lepers (March 2012). Does Employee Ownership Benefit Value Creation? The Case of France (2001-2005), p. 325-40.

\section{Websites}

1. https://www.ibisworld.com

2. https://www.grandviewresearch.com/industry-analysis/ engineering-services-outsourcing-market.

3. https://www.designsociety.org/ off shoring of engineering services.
4. https://www.ibef.org/industry/engineering-india.aspx

5. https://www.indiatechonline.com/special-feature. Php?Id=48

6. https://guides.11.georgetown.edu/employee-benefits

7. https://www.allbusiness.com/7-employee-benefits-thatincrease-productivity-22124-1.html

8. https://www.bls.gov>summer $>$ art02

9. https://kalyan-city.blogspot.in/2013/03/benefits-ofhigher-productivity.html?m=1

10. https://semcon.com

11. https://www.owler.com/company/semcon

12. https:/www.worldcement.com/the-americas/13052016/ semcon-wins-award-102

13. https://www.businesswire.com/news/home/ 20111107005798 /en/MAN-semcon-business

14. https://en.wikipedia.org/wiki/semcon

15. www.4-traders/SEMCON-AB-6491380/news/semconwinner-of-the-volvo-cars-quality Excellence 